\title{
Aquarium trade and fish farms as a source of non-native freshwater fish introductions in French Guiana
}

\author{
Sébastien Brosse ${ }^{1, *}$, Antoine Baglan ${ }^{2}$, Raphael Covain ${ }^{3}$, Hadrien Lalagüe ${ }^{2,4}$, Pierre-Yves Le Bail ${ }^{5}$, \\ Régis Vigouroux ${ }^{6}$ and Grégory Quartarollo ${ }^{2,6}$ \\ ${ }^{1}$ Laboratoire Évolution \& Diversité Biologique (EDB UMR5174), Université Paul Sabatier - Toulouse 3, CNRS, IRD, UPS, 118 route de \\ Narbonne, 31062 Toulouse Cedex, France \\ 2 Guyane Wild Fish, Chez Aprosep, 81 rue Christophe Colomb, 97300 Cayenne, French Guiana \\ 3 Muséum d'histoire naturelle, Herpétologie et Ichtyologie, Route de Malagnou 1, 1211 Genève, Suisse \\ ${ }^{4}$ CNRS, UMR Ecologie des Forêts de Guyane, AgroParisTech, CIRAD, INRA, Université des Antilles, Université de Guyane, Kourou, \\ France \\ ${ }^{5}$ INRAE, UR1037 LPGP, Fish Physiology and Genomics, Campus de Beaulieu, 35000 Rennes, France \\ ${ }^{6}$ HYDRECO, Laboratoire Environnement de Petit Saut, B.P 823, 97388 Kourou Cedex, French Guiana
}

Received: 18 June 2020; Accepted: 7 January 2021

\begin{abstract}
Rivers of French Guiana are still little invaded by non-native fish, but several fish introductions were recently recorded through the development of aquarium fish trade and fish farms. Here we report records of 11 non-native fish species. Among them, four (Cichla monoculus, Heros efasciatus, Mesonauta guyanae and Poecilia reticulata) are established and one of them (Heros efasciatus) is rapidly increasing its spatial range. Two species (Hyphessobrycon eques and Pterophyllum scalare) were not retrieved in recent records and are probably extinct from French Guiana. The establishment status of the five other species (Arapaima gigas, Colossoma macropomum, Cyprinus carpio, Oreochromis mossambicus and Osteoglossum bicirrhosum) is uncertain and only a few specimens were observed in the wild. Nevertheless, these species, intensively reared in nearby countries, belong to highly invasive species able to cause detrimental impacts on recipient ecosystems. Those first occurrences of invasive fish species in French Guiana should therefore act as an early warning for both researchers and environmental managers.
\end{abstract}

Keywords: Biological invasions / invasion pathways / Neotropics / propagule pressure / South America / river

\section{Introduction}

Freshwater fish invasions are widespread across the world (Leprieur et al., 2008) and are recognised as one of the main causes of global changes on aquatic ecosystems (Sala et al., 2000; Butchart et al., 2010). The Neotropical zone was known as less impacted by freshwater fish invasions than the other realms (Leprieur et al., 2008), but recent reports show a growing invasion trend (Daga et al., 2016; Bezerra et al., 2019; Vitule et al., 2019). The establishment of several non-native species in Amazonian rivers had detrimental effects on aquatic ecosystems and native fish communities (Vitule et al., 2009; Pelicice et al., 2017; Bezerra et al., 2019).

French Guiana is bordered by Brazil and Suriname and share with them part of the Maroni and Oyapock (also called

\footnotetext{
*Corresponding author: sebastien.brosse@univ-tlse3.fr
}

Oiapoque) drainages, which represent the border between French Guiana and those two countries (Fig. 1). While Brazil is now recognised as a hotspot for fish biological invasions (Bezerra et al., 2019; Vitule et al., 2019), previous reports record few freshwater fish invasions in French Guiana. Indeed a few ancient introduction attempts did not led to durable establishment of the introduced species. Hyphessobrycon eques (Steindachner, 1882) and Heros efasciatus Heckel, 1840 were the only non-native species reported as established in French Guiana by Planquette et al. (1996) and Keith et al. (2000). Nevertheless, recent reports attest for the establishment of at least one more non-native species, the guppy (Poecilia reticulata), that originates from Trinidad, Tobago and coastal areas of North-East South America, including Venezuela and Guyana (Deacon et al., 2011; Bragança et al., 2020). Moreover, the demographic rise of human population in French Guiana led to trigger the development of aquarium trade and aquaculture, increasing therefore the risk of new 


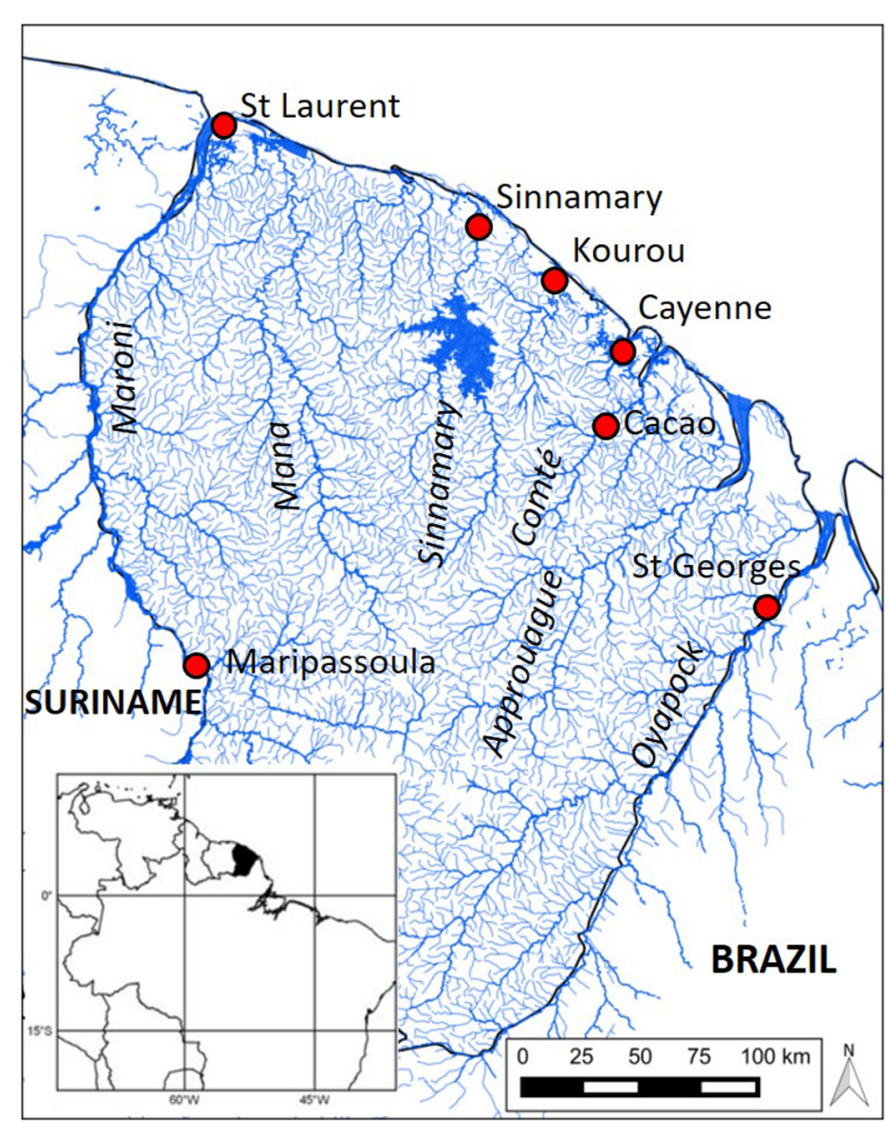

Fig. 1. Map of French Guiana indicating the main river basins and human settlements. Inset map indicate French Guiana location in South America.

introductions of non-native species. Here we made an update of non-native freshwater fish introductions in French Guiana, and indicate the current distribution of those species. Although the impact of those non-native species on the Guianese fauna and ecosystems is still unknown, our work provide a state of the art of non-native fish species introductions in French Guiana.

\section{Material and methods}

We made an exhaustive survey of non-native fish observations and captures in the Guianese freshwaters based on scientific fish inventories, water management surveys and angling reports collected by the NGO Guyane Wild Fish and the HYDRECO laboratory during the last 10 years $(2010$ 2020). All the species were observed and/or collected by the authors and only reports associated to the collection of a specimen or to a good quality picture permitting to certify the species identity were considered. Fish identifications were done according to Planquette et al. (1996), Keith et al. (2000) and Le Bail et al. (2000). The species not described in those identification guides were validated by professional fish taxonomists (RC \& PYLB). All doubtful or unverified information were deleted. A species was considered as nonnative if it does not naturally belongs to the drainage basin where it was observed, excluding therefore natural spread of native species. We therefore considered both non-Guianese species (exotic species) and Guianese species introduced in one or several river basins where they do not naturally belong (translocated species, Leprieur et al., 2008). We however not considered species translocated within the same river basin. Non-native species occurrences were plotted on a map of French Guiana to show their non-native distribution range (Fig. 2), and information about the establishment status of the species were collected. Establishment was considered when stable or spatially expending populations were recorded over the last ten years (2010-2020), with collection of all size and age classes, testifying for the establishment success of the species (sensu Lockwood et al., 2013). When a species was not retrieved in the known introduction locality despite recent ( $>5$ years) and repeated inventories including angling, net catches and underwater observations, it was considered as extinct from the locality.

\section{Results}

Among the 11 non-native fish species recorded on the Guianese territory, two species (Hyphessobrycon eques and Pterophyllum scalare (Schultze, 1823)) were not retrieved in their invasion range in recent records, and nine non-native species are therefore currently present in French Guiana. Among these species, four originate from coastal swamps of Amapá, Brazil and occasionally enter the Oyapock River (Jégu and Keith, 1999; Lemopoulos and Covain, 2019). They are therefore native from the Oyapock drainage basin, which main course represents the frontier between Brazil and French Guiana (Fig. 1). Those species, belonging to the Cichlidae (Cichla monoculus (Spix \& Agassiz, 1831); Heros efasciatus and Mesonauta guyanae (Schindler, 1998)) and Osteoglossidae (Osteoglossum bicirrhosum (Cuvier, 1829)) families were recently observed in other Guianese basins where they do not naturally belong (Fig. 2). One species (Heros efasciatus) established and is rapidly expanding its spatial range. Two other species (Cichla monoculus, and Mesonauta guyanae) also established, with captures of both juveniles and adults for more than 10 years, but did not expended out from their introduced localities (Tab. 1).

Three other species belong to the Neotropical zone, but are naturally absent from French Guiana (Arapaima gigas (Schinz, 1822); Colossoma macropomum (Cuvier, 1816); and Poecilia reticulata (Peters, 1859); Fig. 2). Among these three species, only Poecilia reticulata currently established, whereas only a few observations were reported for the two former species, and their establishment status in French Guiana is therefore uncertain (Tab. 1).

The two last species belong to Eurasia (Common carp, Cyprinus carpio (Linnaeus, 1758)) and Africa (Tilapia, Oreochromis mossambicus (Peters, 1852)). They were reported from few localities in French Guiana and their establishment status remain uncertain (Fig. 2 and Tab. 1).

\section{Discussion}

The Guianese rivers were for long considered pristine, and as an exception compared to most of the world rivers that 

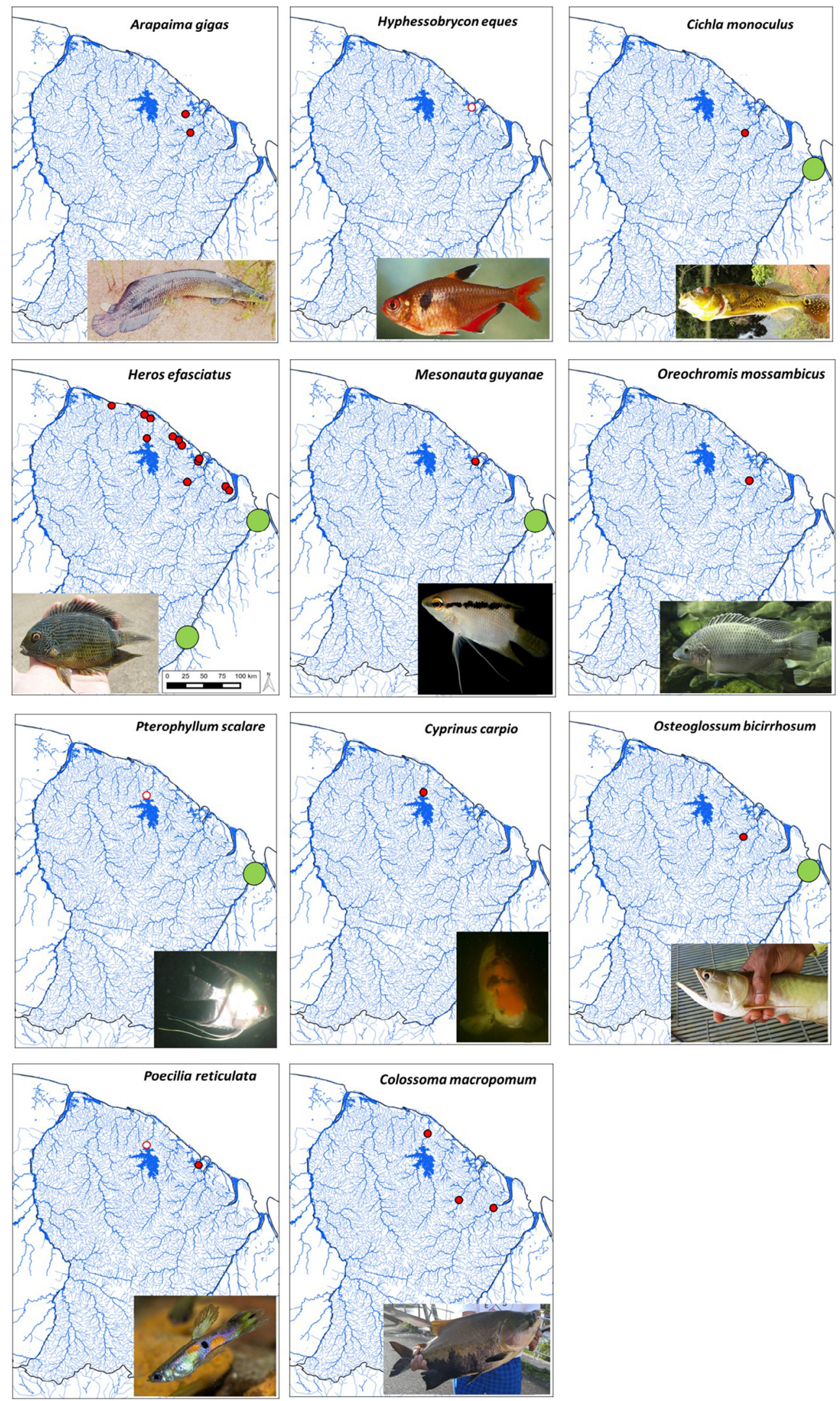

Fig. 2. Distribution maps for the 11 non-native species. Red dots represent current observations and open dots indicate extinct populations. Green dots indicate the native distribution range in French Guiana for the species occurring at least sporadically as native in French Guiana. Photographs are fish observed or collected in French Guiana (photo supplied by the authors), except for Oreochromis mossambicus (photo by G. Hume). 
Table 1. List of the non-native species and families, region or basin of origin, human use, status (established, non-established, extinct or unknown), date of first observation as non-native in French Guiana and river basins where the species has been observed as non-native (AP: Aprouague; CO: Comté; CR: coastal rivers and swamps; OY: Oyapock; SI: Sinnamary).

\begin{tabular}{|c|c|c|c|c|c|c|}
\hline Family & Species name & Native origin & Human use & $\begin{array}{l}\text { Status in } \\
\text { French } \\
\text { Guiana }\end{array}$ & $\begin{array}{l}\text { First observation } \\
\text { in French } \\
\text { Guiana }\end{array}$ & River basins \\
\hline Characidae & $\begin{array}{l}\text { Hyphessobrycon eques } \\
\text { (Steindachner, 1882) }\end{array}$ & $\begin{array}{l}\text { Amazon and } \\
\text { Paraguay }\end{array}$ & Ornamental & Extinct & 1996 & $\mathrm{CR}$ \\
\hline Cichlidae & $\begin{array}{l}\text { Heros efasciatus } \\
\text { (Heckel, 1840) }\end{array}$ & $\begin{array}{l}\text { Amazon and } \\
\text { Oyapock }\end{array}$ & Ornamental & Established & 1984 & $\mathrm{CO}, \mathrm{CR}, \mathrm{OY}, \mathrm{SI}$ \\
\hline Cichlidae & $\begin{array}{l}\text { Mesonauta guyanae } \\
\text { (Schindler, 1998) }\end{array}$ & $\begin{array}{l}\text { Amazon, Essequibo, } \\
\text { Oyapock }\end{array}$ & Ornamental & Established & 2009 & $\mathrm{CR}$ \\
\hline Cichlidae & $\begin{array}{l}\text { Oreochromis mossambicus } \\
\text { (Peters, 1852) }\end{array}$ & Africa & Aquaculture & Unknown & 2003 & $\mathrm{CO}$ \\
\hline Osteoglossidae & $\begin{array}{l}\text { Osteoglossum bicirrhosum } \\
\text { (Cuvier, 1829) }\end{array}$ & Amazon, Oyapock & Aquaculture & Non-established & 2018 & $\mathrm{CO}$ \\
\hline Poecilidae & $\begin{array}{l}\text { Poecilia reticulata } \\
\text { (Peters, 1859) }\end{array}$ & $\begin{array}{l}\text { North-East of } \\
\text { South America }\end{array}$ & Ornamental & Established & 2005 & SI, CR \\
\hline Serrasalmidae & $\begin{array}{l}\text { Colossoma macropomum } \\
\text { (Cuvier, 1816) }\end{array}$ & $\begin{array}{l}\text { Amazon and } \\
\text { Orinoco }\end{array}$ & Aquaculture & Unknown & 2018 & $\mathrm{AP}, \mathrm{CO}, \mathrm{SI}$ \\
\hline
\end{tabular}

experienced several non-native species introductions and subsequent establishment (Leprieur et al., 2008). Indeed, Planquette et al. (1996), Le Bail et al. (2000) and Keith et al. (2000) reported only two non-native fish species in French Guiana. Among these two species, Hyphessobrycon eques was no longer retrieved in French Guiana, and this introduced population is probably currently extinct (Quartarollo and Lalagüe, 2019). In contrast, Heros efasciatus is still present in French Guiana, and its non-native spatial repartition, initially clustered to the vicinity of Kourou (North of French Guiana, Keith et al., 2000) extended to the swamp habitats from most of the Guianese littoral area. Recent observations indicate high densities of the species in the initial introduction area, close to the city of Kourou, and growing populations in the other localities, indicating the species is established and expending. Such spatial range extension can be due to several introduction events, or to the species spread from its initial introduction locality through coastal swamp corridors. We nevertheless cannot exclude a natural spatial expansion of Heros efasciatus to Kaw swamps located ca. 50 kilometres west from the native range of the species.

More than a decade after Planquette et al. (1996), Le Bail et al. (2000) and Keith et al. (2000), an updated checklist of freshwater fish of French Guiana only report one more introduction, with the presence of Poecilia reticulata in the vicinity of Cayenne city (Le Bail et al., 2012). This species is still present in this locality, and established durable populations in the ponds and streams of the Rorota mount, a natural area close to Cayenne. This species has also been introduced in
2016 in a gravel pit located $60 \mathrm{~km}$ east from Cayenne, but this population probably collapsed, because the species was not retrieved in this site since 2018 . In addition to the latter species we here report for the first time the introduction of eight more non-native species in Guianese waters. Although captures or observations of these species are scarce, and establishment status of some species unknown, such observations should be considered as an early signal of potential establishment and subsequent invasion.

The presence of non-native species in Guianese freshwaters should be related to two distinct human activities. Cyprinus carpio (koi strain), Heros efasciatus, Hyphessobrycon eques, Mesonauta guyanae, Poecilia reticulata and Pterophyllum scalare are popular ornamental species, which were probably released in the natural environment by fish hobbyists (i.e. aquarium dumping). This explains their introduced locations nearby cities, to the exception of Cyprinus carpio and Pterophyllum scalare, which were introduced in a gravel pit (Crique Crabe drainage, near the Petit-Saut hydroelectric dam) commonly used by local people for recreation activities and diving. The other species (Arapaima gigas, Colossoma macropomum, Cichla monoculus, Osteoglossum bicirrhosum and Oreochromis mossambicus) are intensively reared in aquaculture farms in Suriname and Brazil, and illegally reared in artisanal fish ponds close to Cacao and Montsinery villages (Cambou \& Thonnel 2010). Some individuals probably escaped from these ponds explaining the occurrence of some of these species in the nearby Comté River. It should nevertheless be noticed that the occurrence of Colossoma macropomum in 
the Approuague and Sinnamary rivers suggest the presence of this species in other fish ponds from the littoral zone of French Guiana.

The non-native species were to date recorded only in the littoral zone of French Guiana, and recent fish inventories did not report captures in other locations (e.g. Allard et al., 2016; Cilleros et al., 2017; Brosse et al., 2013, 2019), indicating that those species did not disperse far from the introduction sites. Nevertheless, the capture of one Colossoma macropomum on the Comte River more than 25 kilometres upstream from Cacao village, the supposed introduction site, attests for the survival and dispersion of the species in Guianese rivers, although its establishment success remains unknown. Among the 11 species, at least four successfully established (Cichla monoculus, Heros efasciatus, Mesonauta guyanae and Poecilia reticulata) in natural swaps and artificial ponds, corresponding to the natural habitat of those species. Cyprinus carpio is known from a single locality, and only adults have been observed, suggesting the species failed to establish. The establishment status of the remaining species (Arapaima gigas, Colossoma macropomum, Osteoglossum bicirrhosum and Oreochromis mossambicus) remain unknown, but they are recognised as potentially invasive species in the literature. Oreochromis mossambicus is indeed one of the most invasive fish species (IUCN, 2020), which established in most tropical regions (Rahel, 2007; Pelicice et al., 2017). Colossoma macropomum and Arapaima gigas were also reported to establish and spread in several Neotropical and Central American localities (Vitule et al., 2009; Van Damme et al., 2015; Pelicice et al., 2017). The establishment of those species is therefore likely in Guianese waters.

Such establishment or the spread of already established species could cause detrimental impacts on the native fauna. Non-native species are indeed recognised as one of the main cause of biodiversity erosion (Butchart et al., 2010) and freshwater fish invasions already had pervasive impacts throughout South America (Vitule et al., 2009; Pelicice et al., 2017). More specifically Cichla invasion has been reported to cause a biodiversity collapse of the lake Panama ecosystem in the seventies (Zaret and Paine, 1973), and Cichla ocellaris, a species closely related to Cichla monoculus, is currently invading the Upper Parana river (Espinola et al., 2015). Tilapia (Oreochromis sp.) severely impacted native Cichlidae species in the Amazonas basin (Bittencourt et al., 2014), and Arapaima gigas rapidly extends its geographical range in the Bolivan Amazon, putting at risk native fish populations (Van Damme et al., 2015). Although the state of invasion of those species in French Guiana is still in an early stage, the current human demographic increase triggers the demand for fish production, and increases risks of further introductions. For instance, the highly invasive armoured catfishes from the Pterygoplichthys genus appear as candidates for forthcoming introduction. Indeed, Pterygoplichthys disjunctivus (Weber, 1991) has been detected in 2010 in lower Suriname River (Suriname), and since then regularly found in Paramaribo fish market where it replace Hypostomus plecostomus (Linnaeus, 1758) (J. Mol, pers. com.). Those fishes already recently dispersed to the West, in lower Saramacca drainage (Makhan, 2017), and might already settled in French Guiana given that Commewijne River, located West of lower Maroni River, shares a common mouth with the Suriname River. Such forthcoming introductions risks are also reinforced by the development of ornamental fish trade. Aquaculture and ornamental trade therefore represent a source of further introductions for the already introduced, but still not established species, as well as a source of new species introductions, as already experienced in Brazilian freshwaters (Junior et al., 2018; Patoka et al., 2018). Increasing both the number of introduced species and introduction events reinforces establishment probability (Leprieur et al., 2008), and given that once a non-native species is established, its control and eradication is almost impossible (Pimentel et al., 2005), the non-native species records reported here should act as an early warning to control and limit further introductions. Such limitation could be achieved through laws banning the potentially invasive species form fish trade, including fish farms and ornamental pet shops that are a major source of nonnative species introductions in the Neotropics (Britton and Orsi 2012; Magalhães and Jacobi 2013; Magalhães et al., 2020). In addition, awareness campaigns are also needed to educate people on the pervasive effects of non-native species, and hence reduce the human assisted spread of already established species.

Acknowledgements. This work has been supported by the LABEX CEBA (ANR-10-LABX-25-01) and TULIP (ANR10-LABX-41), Investissement d'Avenir grants of the French Agence Nationale de la Recherche, as well as by the DGTM and Office de l'Eau Guyane (IQCN project).

\section{References}

Allard L, Popée M, Vigouroux R, Brosse S. 2016. Effect of reduced impact logging and small-scale mining disturbances on Neotropical stream fish assemblages. Aquat Sci 78: 315-325.

Bezerra LAV, Padial AA, Daga VS, Occhi T, Faria L, Prodocimo V, Vitule JRS. 2019. A network meta-analysis of threats to South American fish biodiversity. Fish Fish 20: 620-639.

Bittencourt LS, Silva URL, Silva LMA, Tavares-Dias M. 2014. Impact of the invasion from Nile tilapia on natives Cichlidae species in tributary of Amazonas River, Brazil. Biota Amazônia 4: 88-94.

Bragança PHN, Guimarães EC, De Brito PS, Ottoni FP. 2020. On the natural occurrence of Poecilia reticulata Peters, 1859 (Cyprinodontiformes: Poeciliidae). Cybium 44: 309-316.

Britton JR, Orsi ML. 2012. Non-native fish in aquaculture and sport fishing in Brazil: economic benefits versus risks to fish diversity in the upper River Paraná Basin. Rev Fish Biol Fish 22: 555-565.

Brosse S, Montoya-Burgos JI, Grenouillet G, Surugue N. 2013. Determinants of fish assemblage structure in Mount Itoupé mountain streams (French Guiana). Ann Limnolog 49: 43-49.

Brosse S, Melki F, Vigouroux R. 2019. Fishes of the Mitaraka mountains (French Guiana). Zoosystema 41: 131-151.

Butchart SHM, Walpole M, Collen B, et al. 2010. Global biodiversity: indicators of recent declines. Science 328: 1164-1168.

Cambou J, Thonnel A. 2010. Les invasions biologiques en Guyane. 1e phase: Diagnostic. DIREN Guyane- Biotope-CIRAD. Report 2009378.

Cilleros K, Allard L, Vigouroux R, Brosse S. 2017. Disentangling spatial and environmental determinants of fish species richness and assemblage structure in Neotropical rainforest streams. Freshw Biol 62: 1707-1720. 
Daga VS, Debona T, Abilhoa V, Gubiani ÉA, Vitule JRS. 2016. Non-native fish invasions of a Neotropical ecoregion with high endemism: a review of the Iguaçu River. Aquat Invas 11: 209-223.

Deacon AE, Ranmarine IW, Magurran AE. 2011. How reproductive ecology contributes to the spread of a globally invasive fish. PLOS ONE 6: e24416.

Espinola LAE, Minte-Vera CV, Junior HFJ, Santos LN, Winemiller KO. 2015. Evaluation of factors associated with dynamics of Cichla ocellaris invasion of the Upper Parana river floodplain system, Brazil. Mar Freshw Res 66: 33-40.

IUCN. 2020. Global Invasive Species Database. Species profile: Oreochromis mossambicus. Downloaded from http://www .iucngisd.org/gisd/speciesname/Oreochromis +mossambicus on 14- 06-2020.

Junior DPL, Magalhães ALB, Pelicice FM, Vitule JRS, AzevedoSantos VM, Orsi ML, Simberloff D, Agostinho AA. 2018. Aquaculture expansion in Brazilian freshwaters against the Aichi Biodiversity Targets. Ambio 47: 427-440.

Jegu M, Keith P. 1999. Lower Oyapock River as northern limit for the Western Amazon fish fauna or only a stage in its northward progression. Comp Rend l'Acad Sci Series III Sci 322: 1133-1143.

Keith P, Le Bail P-Y, Planquette P. 2000. Atlas des poissons d'eau douce de Guyane (Batrachoidiformes, Mugiliformes, Beloniformes, Cyprinodontiformes, Synbranchiformes, Perciformes, Pleuronectiformes, Tetraodontiformes). Tome 2, fascicule 1, MNHN Museum National d'Histoire Naturelle Paris: $286 \mathrm{p}$.

Le Bail P-Y, Keith P, Planquette P. 2000. Atlas des poissons d'eau douce de Guyane (Siluriformes). Tome 2, fascicule 2, MNHN Museum National d'Histoire Naturelle Paris: 307 p.

Le Bail P-Y, Covain R, Jegu M, Fisch-Muller S, Vigouroux R, Keith P. 2012. Updated checklist of the freshwater and estuarine fishes of French Guiana. Cybium 36: 293-319.

Lemopoulos A, Covain R. 2019. Biogeography of the freshwater fishes of the Guianas using a partitioned parsimony analysis of endemicity with reappraisal of ecoregional boundaries. Cladistics 35: 106-124.

Leprieur F, Beauchard O, Blanchet S, Oberdorff T, Brosse S. 2008. Fish invasions in the world's river systems: when natural processes are blurred by human activities. PLoS Biol 6: e28.

Lockwood JL, Hoopes MF, Marchetti MP. 2013. Invasion Ecology, 2nd edn. Wiley-Blackwell, 373 p.
Makhan D. 2017. The first record of Pterygoplichthys disjunctivus (Weber, 1991) (Actinopterygii: Loricariidae) from Jarikaba in the District Saramacca, Suriname. Calodema 500: 1-2.

Magalhães ALB, Daga VS, Bezerra LAV, Vitule JRS, Jacobi CM, Silva LGM. 2020. All the colors of the world: biotic homogenizationdifferentiation dynamics of freshwater fish communities on demand of the Brazilian aquarium trade. Hydrobiologia 847: 3897-3915.

Magalhães ALB, Jacobi CM. 2013. Invasion risks posed by ornamental freshwater fish trade to southeastern Brazilian rivers. Neotrop Ichthyol 11: 433-441.

Patoka J, Magalhães ALB, Kouba A, Faulkes Z, Jerikho R, Vitule JRS. 2018. Invasive aquatic pets: failed policies increase risks of harmful invasions. Biodivers Conserv 27: 3037-3046.

Pelicice FM, Azevedo-Santos VM, Vitule JRS, Orsi ML, Lima-Junior DP, Magalhães ALB, Pompeu PS, Petrere-Junior M, et al. 2017. Neotropical freshwater fishes imperilled by unsustainable policies. Fish Fish 18: 1119-1133.

Pimentel D, Zuniga R, Morrison D. 2005. Update on the environmental and economic costs associated with alien-invasive species in the United States. Ecol Econ 52: 273-288.

Planquette P, Keith P, Le Bai P-Y. 1996. Atlas des poissons d'eau douce de Guyane. Tome 1, MNHN Museum National d'Histoire Naturelle Paris: 429 p.

Quartarollo G, Lalagüe H. 2019. Inventaire de l'ichtyofaune de la crique Bernard dans la Reserve Naturelle du Mont Grand Matoury (Guyane Française). GWF report. 15 p.

Rahel F. 2007. Biogeographic barriers, connectivity and homogenization of freshwater faunas: it's a small world after all. Freshw Biol 52: 696-710.

Sala OE, Chapin III FS, Armesto JJ, et al. 2000. Global biodiversity scenarios for the year 2100. Science 287: 1770-1774.

Van Damme PA, Méndez CC, Zapata M, Carvajal-Vallejos FM, Carolsfeld J, Olden JD. 2015. The expansion of Arapaima cf. gigas (Osteoglossiformes: Arapaimidae) in the Bolivian Amazon as informed by citizen and formal science. Manag Biol Invas 6: 375-383.

Vitule JRS, Freire CA, Simberloff D. 2009. Introduction of non-native freshwater fish can certainly be bad. Fish Fish 10: 98-108.

Vitule JRS, Occhi TVT, Kang B, Matsuzaki SI, Bezerra LA, Daga VS, Faria L, Frehse AF, Walter F, Padial AA. 2019. Intra-country introductions unraveling global hotspots of alien fish species. Biodivers Conserv 28: 3037-3043.

Zaret TM, Paine RT. 1973. Species introduction in a tropical lake. Science 182: 449-455.

Cite this article as: Brosse S, Baglan A, Covain R, Lalagüe H, Le Bail P.-Y., Vigouroux R, Quartarollo G. 2021. Aquarium trade and fish farms as a source of non-native freshwater fish introductions in French Guiana. Ann. Limnol. - Int. J. Lim. 57: 4 